\title{
ONLINE COMMUNICATION AND EVERYDAY LIFE: FEMALE SOCIAL AUDIENCE AND TV FICTION
}

\author{
Comunicación online y vida cotidiana: audiencia social femenina y ficción televisiva
}

\author{
Charo Lacalle* \\ Cristina Pujol**
}

\begin{abstract}
The construction of online gender identities around television fiction has been dominated by studies on eminently masculine cult fandoms. This article attempts to overcome this through the specific examination of the construction of online identities of women on social networks and forums dedicated to Spanish television fiction. The methodology employed combines manual techniques (gathering the comments) and computational processes (ATLAS.ti). The results of the analysis reveal that unlike cult fandoms, the female participants of our study do not seek to claim an identity. Instead, they reveal their desire to express and share sentiments and emotions generated through the interrelationship between the programmes and their daily lives. Female cultural identities are not used politically or as a claim.
\end{abstract}

Keywords: Online communication, gender identity, social audience, TV fiction, fandom.

\footnotetext{
* Facultad de Ciencias de la Comunicación, Autonomous University of Barcelona. Barcelona, Spain. E-mail: rosario.lacalle@uab.es

** Facultad de Ciencias de la Comunicación, Autonomous University of Barcelona. Barcelona, Spain. E-mail: cristina.pujol@uab.es

Artículo recibido el 14 de agosto de 2016. Aceptado el 03 de mayo de 2017.
} 


\section{RESUMEN}

La construcción de identidades de género online en torno a la ficción televisiva ha estado dominada por las investigaciones sobre los cult fandom, que son eminentemente masculinos. El artículo intenta superar este punto de vista mediante el examen específico de la construcción identitaria online de las mujeres en las redes sociales y los foros dedicados a la ficción televisiva española. La metodología implementada combina técnicas manuales (recogida de los comentarios) y computacionales (ATLAS.ti). Los resultados del análisis revelan que, a diferencia de los cult fandom, las participantes de nuestro estudio no buscan la reivindicación identitaria, sino que en todo caso muestran su voluntad de expresar y compartir sentimientos y emociones suscitados por la interrelación entre los programas y su vida cotidiana. Tampoco se hace un uso político ni reivindicativo de las identidades culturales femeninas.

Palabras clave: comunicación online, identidad de género, audiencia social, ficción TV, fandom.

\section{INTRODUCTION}

New technologies have changed the ways audio-visual texts are produced and viewed, fostering the construction of trans-media content relations and extending to the virtual world the connections traditionally established around fiction. The paradigm of this media convergence -the result of the development of new communication technologies- is a participative culture (Jenkins, 2006) that lies between artistic expression and civic engagement. Moreover, the Computer Mediated Communication (CMC) is modifying the barriers between media producers and their consumers and contributes to intensifying the experience of cultural consumption by, on the one hand, integrating and stimulating narrative, technological and emotional skills (Black, 2009; Guerrero, 2015) and, on the other, strengthening consumption practices as meaningful practices intimately linked to the construction of cultural identities (Black, 2006).

In this context of participatory culture and online communication, we would like to explore those features of female participation on the Internet that are not exclusive to cult fandom. However, although much of the literature on fandom and genre is useful to situate our study in an online communication context, we are interested in describing the relations of the spectators with their favourite TV fictions in a domestic, daily, generalist television environment. The reason for this is that TV fictions have become an important element of a network identity, changing their relationship with viewers in a qualitative way, opening spaces, providing hashtags and integrating feedback through social networks. 
In this sense, businesses have realised that strengthening interactivity and participation contributes to increasing their profits and have raced to extend television programmes to the Internet with the aim of garnering viewers' loyalty and amplifying their market niches (Scolari, 2015; Siapera, 2015; Wee, 2004). Television is addressing this new ideal consumer, with whom it establishes a synchronous and extended relationship (Deery, 2003, p. 166) and strengthens feedback through new technologies that enable fans to discuss and negotiate the messages' contents (Lacalle \& Castro, 2016). This results in a double feedback mechanism, since while the tactics used by viewers serve to build and strengthen their cultural identities, these are used in turn by cultural industries to create and promote their own contents.

After the surge of first wave authors of studies on fandom, which identified fans' activities with cultural practices (Jenkins, 1992a; Hills, 2002), the influence of Bourdieu on second wave studies shifted attention towards social identity construction through fan communities. The third wave of fan studies, however, seeks "to capture fundamental insights into modern life" (Gray, Sandvoss \& Harrington, 2007, p. 9) and extends the analysis of fandoms beyond cult fans to address the practices of consumption in other areas such as politics (Sandvoss, 2013).

Questions on gender identities occupy a prominent place in studies on fandom. However, although certain myths such as the association of masculinity and cult cinema (Hollows, 2003) or romance and femininity (Hadas, 2013) have been widely questioned, women have historically been underrepresented in the story of fan culture (Coppa, 2006). Thus, while male fandoms were often claimed from the tradition of youth subcultures - underlining the political and resistance aspect implicit in their activities (Jancovich, 2003)-, young female fans were classified as immature consumers (Anderson, 2012, p. 240). By contrast, the new "global" female identities (Kehily \& Nayak, 2008) find in the Internet and in the forms of online participation a form of reaffirmation and reconfiguration built around gender (Carstensen, 2009). The increase in online magazines and blogs written by and for young women demonstrates the redefinition of female identities through an agency that allows them to develop both their collective identity and social posture (Kehily \& Nayak, 2008, p. 337).

The aim of the study is to explore those features of female participation on the Internet that are not exclusive to cult fandom and to describe the specificities of women's communication with generalist open TV fictions in their daily lives, beyond the niches of cult fandom. 


\section{ONLINE FEMALE IDENTITIES AND TELEVISION FICTION}

In her pioneering ethnographic study on online fandom, Baym (1999) demonstrated that participation in these types of communities has become a rite to kindness and friendship "deeply embedded in and influenced by the daily realities of embodied life" (Baym, 2010, p. 152). Thus, the "bedroom culture" of girls (McRobbie \& Garber, 1976) -a refuge far from the male environs of the street or the home patriarchy- has become a global space in which they are virtually connected with their equals. Along the same line, Hollows and Moseley (2006) defend the need to study sociocultural context in order to be able to critically analyse women's consumption practices and understand that the pleasure of reception has become an essential element when analysing the construction of female cultural identities.

The practices of female fandom fall within certain long-standing female cultural traditions such as "sorority", a classic theme of feminism and women's studies incorporated into the world of the Internet and participative culture (boyd, 2007). The idea of a horizontal feminist sisterhood, in contrast to the hierarchy implicit in patriarchy, forms part of a gender-implicit political pact among women who recognise themselves as partners and equals. It is a relational culture based on the principle of reciprocity and the sharing of resources, ideas, tasks, actions, etc. that adopts a logic similar to the current prevailing participative culture. Online communications between women usually go beyond the mere shared consumption of cultural products and often become spaces for socialising and even making friends (Bacon-Smith, 1992; Clark, 2005; boyd, 2007). Wakefield states, in her study on the female community of fans of Scully (X Files, Fox, 1993-2002), that "the group is no longer so much about the fictional FBI agent, but rather the close relationships that the nuns have formed" (Wakefield, 2001, p. 135). However, despite the fact that fans' texts are instantly standardised by being built "in reference to the self rather than forming a reflexive engagement with a text" (Sandvoss, 2005, p. 833), it is evident that the programmes and characters constitute the axis around which female viewers' feedback is structured on the webpages dedicated to television fiction (Evans, 2008; Lacalle, 2013).

Fandom culture corresponds to an eminently female ethic related to gift culture, based on reciprocally giving and receiving and an altruistic purpose (Hellekson, 2009). In this case, the exchanged goods are usually videos, podcasts, fan fiction, forums and reviews, photo galleries, and, above all, opinions and comments (Lacalle \& Castro, 2016), which is the result of certain social relationships that are voluntarily built on the basis of a shared interest. The symbolic exchange

of fandoms (videos, photos, opinions, etc.), carried out behind the backs of the markets, favours the historically female task of maintaining social ties and group cohesion. Thus, female fan culture does not interest itself in the economy 
(predominantly masculine) but in the social sphere (predominantly feminine). Meyen, Pfaff-Rüdiger and Dudenhöffer (2010) observe that men use Internet in a intensive and professional way, while women are more interested in contacting friends and relatives on the Web.

Online fandoms establish networks of virtual relationships that stimulate the development of skills traditionally associated with women (Scott, 2009), including communication skills, a culture of feelings, a taste for detail, an inclination for consumption, etc. Bury (2005) believes that the construction of feminine spaces on the Internet is based on the characteristics typical of the communicative strategies of women and on their desire to use "correct" language. Thomas (2011) attributes to female fandoms a much more conciliatory posture than that adopted generally in male fan groups.

Women are expressive mainly on social networks (Parkins, 2012) and their generalised desire not to offend the community has led to emoticons becoming frequent elements in female messages to express feelings such as solidarity, the assertion of positive sentiments or appreciation (Wolf, 2000). The respect for taking turns to speak or the frequent attempts to mitigate disagreements (Bury, 2005) similarly represent strategies much more frequent to female fandoms than male fandoms (Kapidzic \& Herring, 2011).

\section{METHOD}

This study, carried out within the framework of a wider investigation on the construction of female identity in the Internet 2.0, examines the nature of the interactions of female viewers of Spanish television fiction on social networks and forums dedicated to the programmes to explore those features of female participation on the Internet 2.0 that are not exclusive to cult fandom. The questions this investigation aims to answer are:

Q.1: Does the participation of female spectators on social networks of Spanish television fiction shape a feeling of belonging to a community of fans or is it more a recreational activity in which to share emotions and feelings?

Q.2: Can we talk of a generalised relational style characterised by empathy and warmth?

Q.3: Do female social viewers use television fictions to affirm their female identity? Q.4: Do comments on Spanish fiction adopt the strategies of cult fandoms?

The methodology used here to answer the four questions combines manual techniques (gathering comments) and computational techniques (classification 
using the content analysis software ATLAS.ti) to analyse the comments posted by female viewers and community managers on 157 platforms (49 Facebook pages, 71 Twitter accounts and 37 forums) associated with 72 Spanish programmes broadcast between 2012 and 2013. Usernames and message content were considered verbal cues to identify Internet users' gender (Spottswood et al., 2013), as well as photographs and other indicators such as the gender and adjective agreement of the comments' language -Spanish, Catalan, Galician and Basque. The collecting of 50 units per Internet website was conducted the day after the end of the programme's season, considered by fans as a 'significant event' (Barkhuus and Brown, 2009, p. 13; Larsen, 2010, p. 158). Where there were not enough messages, the sample was completed retrospectively to make up the required 50 .

The classification of the comments was carried on by following a sociosemiotic script elaborated after the viewing of the TV shows. The interpretive process then took place once the tagging had been concluded and the units of analysis had been filtered by code. The codebook was structured into six sections: descriptive codes, narrative world, expression of self-identity, expression of collective identity, social issues and other aspects. The analysis of the comments, carried out after coding, explores the relationship of the female viewers with the programmes that emerges from their interactive experiences with other female users.

\section{RESULTS}

The tagging of the 7,849 units making up the sample generated 22,301 items ${ }^{1}$. In general, the messages of social female viewers present a markedly colloquial and non-standard discourse characterised by immediacy, spontaneity, improvisation and especially, for flexibility and spelling mistakes, and which is frequently illustrated with emoticons, abbreviations and onomatopoeias $38.0 \%$ of the comments $(\mathrm{N}=2,980)$ address the stories and $18.1 \%(\mathrm{~N}=1,422)$, the characters. The emotional connection of the social audience with the plots is generally positive ( $43.5 \% ; \mathrm{N}=1,297)$ or neutral $(\mathrm{N}=1,242 ; 41.67 \%)$, while negative reviews represent $23.8 \%(\mathrm{~N}=709 ; 23.8 \%) .42 .0 \%(\mathrm{~N}=597)$ of comments about the characters are positive, $22.0 \%(\mathrm{~N}=131)$ negative and $42.9 \%(\mathrm{~N}=610)$ neutral.

Facebook is the social network most used to share both positive $(50.6 \%$; $\mathrm{N}=627$ comments) and negative sentiments (43.9\%; $\mathrm{N}=311$ ) on the programmes' contents, followed by Twitter, with $28.4 \%$ of the positive $(\mathrm{N}=352)$ and $25.6 \%$ of the neutral comments $(\mathrm{N}=209)$. The conversational nature of the forums,

\footnotetext{
${ }^{1}$ The complexity of a discursive union derives from the inclusion of various variables and subcategories in a single message.
} 
by contrast, encourages female users to discuss their opinions in a neutral tone (52.9\%; $\mathrm{N}=432$ ), providing summaries or sharing data from external sources (for example, newspapers or specialised websites). Similarly, forums form the second most used space to post critical messages $(38.4 \% ; \mathrm{N}=272)$. In terms of the official discourse, Twitter is the network resource most used by community managers and aggregates $69.0 \%(\mathrm{~N}=40)$ of positive messages and $62.9 \%(\mathrm{~N}=268)$ of neutral messages.

Sentimental and historical themes are issues most addressed by female viewers, although comments emphasise issues of public interest in particular, such as cancer or sexual abuse. The comments never denigrate the physical appearance of the characters. However, they do criticise the cast or the unflattering choice of wardrobe. The physical attractiveness of the characters is not a decisive factor in evaluating the programme, with the strongest female characters being the most admired by female viewers. Open or sudden endings are the issues most criticised by female viewers.

The desire to socialise the pleasure of viewing leads female participants to liberally share personal information. Thus, $43.3 \%(\mathrm{~N}=1,081)$ of the self-reflective messages allude to female users' intimacy, include biographical information, underline the role of the fiction in the structuring of the week and inform of the domestic routines of viewing.

The forums dedicated to the programmes enable female participants to construct their own spaces through which they generate a certain feeling of community ("What I love is that thanks to the programme we have come to know each other and made these wonderful friendships", Amar en tiempos revueltos, La1) which, on occasions, attempts to go beyond the virtual world ("we're now in contact through other means... and I'm looking forward to meeting you all in person...", Bandolera, Antena3). This feeling of unity also manifests itself in the protests against certain decisions taken by the television channels, such as the cancellation of the series due to low audience levels.

Online viewing allows geographical barriers of those female spectators who follow Spanish series from other countries to be overcome, which arouses a certain feeling of nostalgia and a desire to maintain emotional and social ties with their place of origin through the programme ("I insist: you should measure the audience from this side of the Atlantic"). Regional references by female participants are also frequent: ("We in Mallorca don't want the series to end either!!").

In reference to the structure and expressive resources of the messages of the social discourses, the repeated use of signs of admiration, the lengthening or separation of letters and the use of capital letters ("fantaaaassssttic!!", "E-P-I-C", "SOOOOO UNFAIR") give greater emphasis to the comments, while the use of colloquial words or terms used by the young ("nice one", "superb series", "ace", 
"brilliantly made", "wicked", "fab", "wtf?") indicate the generational closeness of the female users. Social female viewers use questions to show their dismay ("Seriously...what on Earth are Carlos and Ariadna on about?", La Riera, TV3). Finally, it should be pointed out that Twitter is the social network that includes the greatest number of emoticons $(53.2 \% ; \mathrm{N}=368)$, followed by forums $(31.0 \%$; $\mathrm{N}=214)$, while Facebook (15.8\%; $\mathrm{N}=110)$ makes a more limited use of both emoticons and gifts. Most of the emoticons used have a social use, since they are used by female viewers both as a way of showing appreciation for the contributions of other members of the community and as courtesy protocols in the interactions. The contribution of emoticons to the conversation, which transcends their merely paratextual nature (Jibril \& Abdullah, 2013), is highlighted when observing their frequent association with expressions of friendship, such as in the following conversation:

Lobita79 - 22/10/2013 - 09:01

Can't wait to see the next. :) Hugs

bluee you don't need to thank me :)

There you go bluee the record lace curtain :DD

$\cdots$

A hug, my sewing buddies ;)

...

bluee, in the mornings I'm working and last night I was with my little eagle :) but I'll keep an eye out in the evenings and let's see if they repeat it tomorrow evening ;)

$\cdots$

It's great to see familiar faces ;) April kisses.

(El tiempo entre costuras [The time between seams], Antena3)

\section{DISCUSSION}

The women's emotional links with the stories are generally positive, which contributes to converting their comments into a rite to kindness and friendship, which is a particularly relevant characteristic considering that the role of the Internet facilitates the spread of emotions (Guadagno et al., 2013, p. 2318). The absence of denigrating expressions, controversies or disputes, is reflected in the repeated use of emoticons and other strategies destined to emphasise comments, such as exclamation marks and capital letters (Bury, 2005). The vocabulary used, 
close to the colloquial language of the young, simulates generational proximity and the importance of heeding the sociocultural context of the participants (Hollows \& Moseley, 2006).

Despite the fact that female viewers are aware that communication is conditioned by the series' lengths, forums become spaces for socialising, including making friends (Bacon-Smith, 1992; boyd, 2007; Clark, 2005). The search for an interpretive consensus, corroborated by the lack of anti-fan webpages, generates a semiosphere in which female participants build their own "sense of community" (Bury, 2005), which they frequently mention. The female participants establish networks of virtual relationships that stimulate the development of skills traditionally associated with women, such as a culture of affection, generosity, a taste for detail or the propensity for consumption (boyd, 2007; Scott, 2009), although the low number of explicit interactions brings into question the socialising nature that Brandtzaeg and Hein (2012) attribute to the interventions of users of social networks. Consequently, it is not possible to confirm that female viewers of Spanish television fiction use the resources dedicated to the programmes to assert their gender identity (Cartensen, 2009), although the expressive forms and courteous tone correspond to the new "global" female identities defined by Kehily and Nayak (2008). Origin, by contrast, is a striking aspect in the emotional relationship with Spanish television fiction (Castelló, 2010), expressed through feelings of nostalgia or belonging, although it coexists with other global identities built as communities of interest around the programmes, such as female Latin American viewers of Spanish series.

The plots and characters form the axis around which female viewers' feedback is structured on the Internet pages dedicated to television fiction (Evans, 2008; Lacalle, 2013). However, the desire to socialise the pleasure of watching leads female viewers to freely share personal information about their lives and daily activities. In this regard, it can be said that female participants connect fiction with their lives (Russell et al., 2003) and convert it into a reference of themselves and their own surroundings (Haimovich, 2002, p. 89). Reception is frequently extended beyond the act of consumption into spaces of interpersonal relationships in daily life.

Finally, the overwhelming use of Twitter by community managers highlights the role of this social network in the construction and maintenance of power relations between television channels and their audiences (Bennett, 2013, p. 132). 


\section{CONCLUSIONS}

The study enables us to answer in the affirmative the first two questions posed at the beginning of the investigation in relation to the recreational nature of interactions aimed at sharing emotions and feelings (Q.1) and the existence of a style of relationship characterised by empathy and warmth (Q.2). In contrast, no evidence has been found that comments on the fictions analysed are a way of affirming the female identity of female spectators (Q.3). Neither have we been able to confirm that the feeling of community generated through interactions aims to build a differentiating social space characteristic of cult fandoms (Q.4).

Despite the fact that the Internet may be a space of great liberating potential capable of constructing alternative and innovative identities that enable biological determinations to be overcome (Halberstam, 2005; Eklund, 2011), our study confirms that "the social structures that shape us and our potentials manifest in our communication, identities, relationships, communities and networks online just as they do offline" (Baym, 2010, p. 71). Female users do not represent cult fandom collectives; they are mostly "posters" and "lurkers" (Sun, Rau \& Ma, 2014, p. 110), with a variable degree of activity, and their relationship with the programmes is intimately related with their daily lives. Neither are female cultural identities used in a political sense or as a claim. Rather, participation is an extension of their offline identity, without apparent conflict (Dirksen et al., 2010). In this regard, it can be said that the interventions reflect instead the coming together of individual positions (Sandvoss, 2013, p. 286) within the logic of a participative culture rather than a defined political action.

Similarly, the results show that the participation of female spectators with the texts adopts many of the media skills associated with cult fandom, with gender being the truly differentiating variable. However, while cult viewers (both men and women) focus on building spaces of social distinction, the female participants in our study do not seek to claim an identity. Rather, they show their desire to express and share feelings and emotions aroused by the programmes, an expression that reflects a very female way of participating far from the traditional controversies of youth subcultures and cult fandoms aimed at building an eminently affectionate and emotional relationship with the television fiction through their daily lives. It remains to be determined in future investigations whether the generalised courtesy of the interventions contributes to the "moral education" of female users through measured communication (Chouliaraki, 2008) or whether, in contrast, it illustrates the union of public and private spheres characteristic of "emotional capitalism" (Illouz, 2007), which finds a perfect place on Internet social sites. 


\section{REFERENCES}

Anderson, Tonja. "Still kissing their poster goodnight: Female fandom and the politics of popular music", Journal of Audience \& Reception Studies 9/2 (2012): 239-264.

Bacon-Smith, Camille. Enterprising woman: Television fandom and the creation of the popular myth. Philadelphia: University of Pennsylvania Press, 1992.

Barkhuus, Louise; Brown, Barry. "Unpacking the Television: User Practices around a Changing Technology", ACM Transactions on Computer-Human Interaction, 19/3 (2009): 1-22. http://dx.doi.org/10.1145/1592440.1592444.

Baym, Nancy. Tune in, log on. Soaps, fandom and online community. Thousand Oaks, CA: Sage, 1999.

Baym, Nancy. Personal connections in the digital age. Malden MA: Polity Press, 2010.

Bennet, Lucy. "Researching online fandom". Cinema Journal 52/4 (2013): 129-134. Retrieved from: http://muse.jhu.edu/journals/cj/summary/v052/52.4.bennett. html. doi:10.1353/cj.2013.0033.

Black, Rebecca W. "Language, culture and identity in online fanfiction". E-Learning 3/2, (2006): 170-184. doi:10.2304/elea.2006.3.2.170.

Black, Rebecca W. "English-language learners, fan communities, and 21st-century skills", Journal of Adolescent \& Adult Literacy 52/8 (2009): 688-697. Retrieved from: http://amberhathaway613.wikispaces.umb.edu/file/view/ RebeccaBlackFanfiction.pdf. doi:10.1598/JAAL.52.8.4.

Booth, Paul. "The television social network: Exploring tv characters", Communication Studies, 63/3 (2012): 309-327. doi:10.1080/10510974.2012.674616.

Boyd, Danah. "Why youth (heart) social network sites: The role of networked publics in teenage social life", Youth, identity, and digital media. David Buckingham (Ed.). Cambridge, MA: MIT Press, (2007): 119-142.

Brandtzaeg, Petter B. \& Heim, J. "A typology of social networking sites users", International Journal of Web Based 7/1 (2011): 28-51. doi:10.1504/ ijwbc.2011.038124. 
Bury, Rhianon. Cyberspaces of their own. Female fandoms online. Peter Lang International Academic Publishers, 2005.

Carstensen, Tanja. "Gender trouble in web 2.0. Gender relations in social network sites, wikis and weblogs", International Journal of Gender, Science and Technology 1/1 (2009): 105-127.

Castello, Enric. "Dramatizing proximity. Cultural and social discourses in soap operas from production to reception", European Journal of Cultural Studies, 13/2 (2010): 207-223. doi:10.1177/1367549409352274.

Chouliaraki, Lilie. "The media as moral education: Mediation and action”, Media, Culture \& Society 30/6 (2008): 831-852. doi:10.1177/0163443708096096.

Clark, Lynn S. "The constant contact generation: Exploring teen friendship networks online". Girls wide web. Girls, the Internet and the negotiation of identity. In Sharon R. Mazzarella (Ed.). New York: Peter Lang, (2005): 203-222.

Coppa, Francesca. "A brief history of media fandom". Fan fiction and fan communities in the age of the Internet. In Hellekson, K. \& Busse, K. (Eds.). North Carolina: McFarland, (2006): 41-60.

Deery, June. "TV.com: Participatory viewing on the web”. The Journal of Popular Culture 37/2 (2003): 161-183. doi:10.1111/1540-5931.00062.

Dirksen, Vanessa, Huizing, Ard \& Smit, Bas. “Piling on layers of understanding': the use of connective ethnography for the study of (online) work practices." New Media and Society 12/7 (2010): 1045-1063. Retrieved from http:// nms.sagepub.com/content/12/7/1045. doi: 10.1177/1461444809341437.

Eklund, Lina. "Doing gender in cyberspace. The performance of gender by female world of warkraft players", Convergence 17/3 (2011): 323-342.

Evans, Elisabeth J. "Character, audience agency and transmedia drama”, Media Culture Society 30/2 (2008): 197-213. doi:10.1177/0163443707086861.

Gray, Johnattan, Sanvoss, Cornell, \& Harrington C. Lee. Why Study Fans?. Fandom: Identities and communities in a mediated world. In Johnattan Gray, Cornell Sanvoss \& C. Lee Harrington (Eds.).New York: NYU Press, (2007) 1-18. 
Guadagno, Rosanna E., Rempala. Daniel M., Murphy, Shannon \& Okdie, Bradley M. "What makes a video go viral? An analysis of emotional contagion and Internet memes", Computers in Human Behavior 29 (2013): 2312-2319. doi:10.1016/j.chb.2013.04.016.

Guerrero, Mar. "Producción y lectura de fan fiction en la comunidad online de la serie Fringe: transmedialidad, competencia y alfabetización mediática”, Palabra Clave 18/3 (2015): 722-745. doi:10.5294/pacla.2015.18.3.5.

Hadas, Leonora. "Resisting the romance: 'Shipping' and the discourse of genre uniqueness in Doctor Who fandom", European Journal of Cultural Studies 16/3 (2013): 329-343. doi:10.1177/1367549413476011.

Haimovich, Perla. "Los jóvenes en la tele. Vidas imaginarias (caso Gran Hermano, Al salir de clase, Crónicas Marcianas, El Rayo)". Los jóvenes y la cultura del ocio. Diversas perspectivas y experiencias en el ámbito local. Alicante: Instituto Alicantino de Cultura y Ayuntamiento de Elche, (2002): 85-103.

Halberstam, Judith. J. In a queer time and place. Transgender bodies, subcultural lives. New York: New York University Press, 2005.

Hellekson, Karen. "A fannish field of value: Online fan gift culture", Cinema Journal, 48/4 (2009): 113-118. doi:10.1353/cj.0.0140.

Hellekson, Karen \& Busse Kristina. "Work in progress". Fan fiction and fan communities in the age of the Internet. Karen Hellekson \& Kristina Busse (Eds.). North Carolina: McFarland, (2006): 5-32.

Hills, Matt. Fan Cultures. London: Routledge, 2003. doi:10.4324/9780203361337.

Hollows, Joanne. "The masculinity of cult". In M. Jancovich, A. Lázaro-Reboll, J. Stringer \& A. Willis. Defining cult movies: The cultural politics of oppositional taste. Manchester: Manchester University Press, (2003): 35-53.

Hollows, Joanne. \& Moseley, Rachel. "Popularity Contests: The Meanings of Popular Feminism”. Feminism in popular culture. Hollows, Joanne. \& Moseley, Rachel. (Eds.). Oxford: Berg, (2006): 1-24.

Illouz, Eva. Cold intimacies. The making of emotional capitalism. Malden, MA: Polity Press, 2007. 
Jancovich, Mark, Lázaro-Reboll, Antonio, Stringer, Julian \& Willis, Andy. "Introduction". Defining cult movies: The cultural politics of oppositional taste. In Mark Jancovich, Antonio Lázaro-Reboll, Julian Stringer, Julian \& Andy Willis (Eds.). Manchester University Press, (2003): 1-13.

Jenkins, Henry. Textual poachers. Television, fans and participatory culture. New York: Routledge: 1992a.

Jenkins, Henry. "'Strangers no more, we sing': Filking and the social construction of the science fiction fan community". The adoring audience: Fan culture and popular media. In Lisa A. Lewis (Ed.). London: Routledge, (1992b): 208-236.

Jenkins Henry. Convergence culture: Where old and new media collide. New York: New York University, 2006.

Jibril, Tanimu A. \& Abdullah, Mardziah H. "Relevance of emoticons in computermediated communication contexts: An overview", Asian Social Science 9/4 (2013): 201-207. doi:10.5539/ass.v9n4p201.

Kapidzic, Sanja. \& Herring, Susan C. "Gender, communication and selfpresentation in teen chatrooms revisited: Have patterns changed?”, Journal of Computer-Mediated Communication 17/1 (2011): 39-59. doi:10.1111/ j.1083-6101.2011.01561.x.

Kehily, Mary J. \& Nayak, Anoop. "Global femininities: Consumption, culture and the significance of place", Discourse: Studies in the Cultural Politics of Education 29/3 (2008): 325-342. doi:10.1080/01596300802259103.

Larsen, Peter. "The grey area. A rough guide. Television fans, internet forums, and the cultural public sphere". Relocating television. Television in the digital context. In Jostein Gripsrud (Ed.). New York: Routledge, (2010): 157-168.

McRobbie, Angela. \& Garber, Jenny. "Girls and subcultures". Resistance through rituals: Youth subcultures in post-war Britain. In Stuart Hall \& T. Jefferson (Eds.). Essex: Hutchinson University Library, (1976): 209-222.

Meyen, Michael, Pfaff-Rüdiger, Senta, Dudenhöffer, Kathrin \& Huss, Julia. "The internet in everyday life: a typology of internet users", Media, Culture \& Society 32/5 (2010): 873-882. doi: 10.1177/0163443710374792. 
Parkins, Róisín. "Gender and prosodic features in emotional expression”, Griffith Working Papers in Pragmatics and Intercultural Communication 5/1 (2012): 46-54.

Ross, Sharon M. Beyond the box. Television and the Internet. Malden, MA: Blackwell, 2008. doi:10.1002/9781444304817.

Russell, Cristel. A., Norman, Andrew T. \& Heckler, Susan E. "People and 'their' television shows: An overview of television connectedness". The psychology of entertainment media. In L. J. Shrum (Ed.). Mahwah, New Jersey: LEA, (2003): 275-291.

Sandvoss, Cornell. Fans: The mirror of consumption. Cambridge: Polity Press, 2005.

Sandvoss, Cornell. "Toward an understanding of political enthusiasm as media fandom: Blogging, fan productivity and affect in American politics", Participations 10/1 (2013): 252-296.

Scolari, Carlos. A. "Transmedia storytelling: Brands, narratives and storyworlds". Handbook of brand semiotics. In G. Rossolatos (Ed.). Kassel: Kassel University Press, (2015): 151-169.

Scott, Suzanne. "Repackaging fan culture. The regifting economy of ancillary content models", Transformative Works and Cultures 3 (2009). Retrieved from http:// journal.transformativeworks.org/index.php/twc/article/view/150/122. doi:10.3983/twc.2009.0150.

Siapera, Eugenia. "From couch potatoes to cybernauts? The expanding notion of the audience on tv channels' websites", New Media \& Society 6/2 (2015): 155-172. doi:10.1177/1461444804041446.

Spottswood, Erin L.; Walther, Joseph B.; Holmstrom, Amanda J.; Ellison, Nicole B. "Person-Centered Emotional Support and Gender Attributions in Computer-Mediated Communication", Human Communication Research, 39/3 (2013): 295-316. http://dx.doi.org/10.1111/hcre.12006.

Stein, Louisa E. Millenial fandom. Television audiences in the transmedia. Iowa: University of Iowa Press, 2013.

Sun, Na, Rau, Patrick Pei-Luen \& Ma, Liang. "Understanding Lurkers in Online Communities: A Literature Review", Computers in Human Behavior 38 (2014):110-117.doi:10.1016/j.chb.2014.05.0scott22. 
Thomas, Bronwen. "What is fanfiction and why are people saying such nice things about it?", StoryWorlds: A Journal of Narrative Studies 3 (2011): 1-24. doi:10.5250/storyworlds.3.2011.0001.

Wakefield, Sarah R. "Your sister in St. Skully: An electronic community of female fans of the X-Files", Journal of Popular Film and Television 29/3 (2001): 130-137. doi:10.1080/01956050109601018.

Wee, Valerie. "Selling teen culture: How the American multi-media conglomeration reshaped teen television in the 1990s". Teen tv: Genre, consumption and identity. In G. Davies \& K. Dickinson (Eds.). London: BFI, (2004): 87-98.

Wolf, Alecia. "Emotional expression online: Gender differences in emoticon use", Cyberpsychology \& Behavior 3/5 (2000): 827-833. doi:10.1089/10949310050191809. 